1 Fundação Oswaldo Cruz (Fiocruz), Escola Politécnica de Saúde Joaquim Venâncio (EPSJV)

- Rio de Janeiro (RJ), Brasil. ariadna.alvarez@fiocruz.br

2 Instituto Federal de Educação, Ciência e Tecnologia do Rio de Janeiro (IFRJ) - Rio de Janeiro (RJ), Brasil.

3 Universidade do Estado do Rio de Janeiro (Uerj), Instituto de Medicina Social (IMS) - Rio de Janeiro (RJ), Brasil.

\section{For a policy of conviviality: institutional movements in the Brazilian Psychiatric Reform}

\author{
Por uma política da convivência: movimentos instituintes na Reforma \\ Psiquiátrica Brasileira
}

Ariadna Patricia Estevez Alvarez $\mathbf{1}^{1}$ Neli Maria de Castro Almeida ${ }^{2}$, Angela Pereira Figueiredo ${ }^{\mathbf{3}}$

DOI: $10.1590 / 0103-11042020127251$

\begin{abstract}
This article intends to give visibility to the process of constitution and implementation of the Permanent Forum of Community and Cultural Centers (Ceco) in the state of Rio de Janeiro. Its inception, theoretical assumptions, and legal, ethical, and political developments among the Brazilian Psychiatric Reform have been described. The Forum's experience has provided three methodological clues, which are useful to design policies: 1) To be opened to everybody's participation, without restrictions; 2) to move without being stuck at the same place; 3) Multiplicity, the desire of the differences without obstructing the path along the way. As a product of this instituted movement, Law No. 4,563/2018 has been collectively generated to create the Community and Cultural Center's policy of the psychosocial network, in Rio de Janeiro, which has been presented by the parliamentary front in defense of mental health and the anti-asylum struggle at the Legislative Assembly of the State of Rio de Janeiro. The movement related to the Ceco, which are important devices to promote meetings in the city, is supported by the production of what is common and is aimed at the sustainability of conviviality in order to resist the dismantling of our public health system and neoliberalism.
\end{abstract}

KEYWORDS Centers of connivance and leisure. Mental health. Health policies.

RESUMO O propósito do artigo foi visibilizar o processo de constituição e implantação do Fórum Permanente de Centros de Convivência e Cultura (Ceco) no estado do Rio de Janeiro. Descreveram-se as etapas de sua gênese, os pressupostos teóricos de sua formulação e os desdobramentos legais, éticos e políticos dos dispositivos de convivência no âmbito da Reforma Psiquiátrica Brasileira. A experiência do Fórum forneceu três pistas metodológicas que podem ser úteis para a construção de políticas: 1) abertura, estar aberto à participação de todos, não restringir; 2) itinerância, movimentar-se sem se fixar em um mesmo lugar; 3) multiplicidade, desejar as diferenças e não obstruir o trânsito entre elas. Como produto desse movimento instituinte, foi gerado coletivamente o Projeto de Lei $n^{\circ} 4.563 / 2018$, que cria a Política Estadual dos Centros de Convivência da Rede de Atenção Psicossocial no estado do Rio de Janeiro, apresentado pela frente parlamentar em defesa da saúde mental e luta antimanicomial na Assembleia Legislativa do Estado do Rio de Janeiro. O movimento em torno dos Ceco, dispositivos de promoção de encontros na cidade, sustenta-se a partir da produção do comum e busca dar sustentabilidade à política da convivência que resiste às tentativas de desmonte do SUS e ao neoliberalismo.

PALAVRAS-CHAVE Centros de convivência e lazer. Saúde mental. Políticas de saúde. 


\section{Introduction}

The objective of the article is to give visibility to the process of constitution and implantation of the Permanent Forum of Community and Culture Centers (Ceco) in the state of Rio de Janeiro, seeking to describe the stages of its inception, the theoretical assumptions of its formulation and, above all, the legal, ethical and political developments of the coexistence devices within the scope of the Brazilian Psychiatric Reform (RPB).

It is an instituted movement of articulation between users, workers, family members, students, researchers, and managers linked to the field of psychosocial care and anti-asylum struggle. This group of subjects who produce knowledge through their political existence took on the responsibility of problematizing and addressing issues related to the policy of conviviality in mental health and related topics such as social inclusion, right to have access to work, education, leisure, culture, and the city.

It consists of a collective experience of propositional debate around practices related to conviviality devices, which recognizes the important advances in the field of psychosocial care and, at the same time, questions the need for new devices capable of establishing a dialog with the rise of new demands of inclusion of insanity in social territories, based on the RPB's own trajectory.

RPB is understood here as a complex political and social process, consisting of players, institutions, and forces from different origins, which affects different territories, in the federal, state, and municipal governments, universities, the health services market, professional councils, associations of people with mental disorders and their families, social movements and the territories of social imagery and public opinion. The psychiatric reform process, understood as a set of transformations of practices, knowledge, cultural and social values and present in the daily life of institutions, services, and interpersonal relationships, advances, although marked by deadlocks, tensions, conflicts, and challenges ${ }^{1}$.

The initial milestone of this movement, which gave rise to the Forum, was the 'I Meeting of generating employment and income, culture and mental health: public policies, community centers, social inclusion through work and art and culture programs', which was a meeting on job and income generation, culture, and mental health: public policies, social centers, social inclusion through work and art and culture programs, held in May 2018 at the State University of Rio de Janeiro (Uerj). The meeting, which had wide popular participation, focused on the discussion about the practices of generating work and income through the joint construction of a policy to implement the Ceco as a health promotion strategy in the state of Rio de Janeiro.

Therefore, this article is a product of the movement initiated around the Ceco device, to report the collective experience of the Forum. It also constitutes an excerpt of the doctoral research of the first author, which was developed at the time of the Forum meetings (starting in May 2018, with eight editions until November 2019).

All authors, besides being researchers, are militants of the movement established around the device. In this sense, we believe that the production of knowledge must take place intrinsically to the social movement, in constant dialog with its players. The production of knowledge occurs when addressing the experience of practice, in which we are all protagonists, searching for the construction of public policies that value both the maintenance and the expansion of the health network devices, in defense of the actions that sustain the RPB and the public health.

Regarding public health policies and the place that Ceco have occupied throughout the history of RPB, it is possible to state that this place transits between marginality, inclusion, and exclusion of the borders of what is instituted and what is instituting. According to Baremblitt ${ }^{2}$, the instituting appears as a process, while the instituted emerges as a 
result. The instituting transmits a dynamic characteristic, the instituted transmits a stabilized characteristic. As life is pure variation, there is a permanent game between instituted forms and instituting movements.

Regarding the legislation that configures this device, Ordinance No. 396, of July 7, 2005, which established the guidelines for Ceco, is mentioned by the Ministry of Health in the report 'Saúde Mental em Dados 11' (Mental Health in Data 11) ${ }^{3}$. However, in the same year of 2005 , the ordinance was revoked, and there was no creation of a new federal norm for its operation, financing or implementation ${ }^{4}$, which weakens the support of the Ceco.

With Ordinance No. 3,088, of December 23, 20115, which instituted the Psychosocial Care Network (Raps) within the scope of the Unified Health System (SUS), Ceco are provided for in primary care. Item III of this ordinance establishes that the Conviviality Center is a public unit, linked to the Health Care Networks, especially to Raps, in which spaces for sociability, production, and intervention in culture and in the city are offered to the general population. Paragraph 4 of this ordinance states that the Conviviality Centers are strategic for the social inclusion of people with mental disorders and those who use crack, alcohol, and other drugs, through the construction of spaces for socializing and sustaining differences in the community and in various areas of the city. Ordinance No. 3,588, of December 21, $2017^{6}$, the one referred to as 'Raps of retrogression', briefly proposes the reintroduction of the day hospital, the institution of the Psychosocial Care Center for Alcohol and Drugs (Caps AD) type IV, which is part of a strategy to finance therapeutic communities, and the reinstatement of outpatient and hierarchical outpatient clinics, going against care based on psychosocial practices. Ceco, as well as street offices, are not included in the official text of the country's mental health policy.

Ferigato et al. ${ }^{\text {(92) }}$ define them as multifaceted devices, or as "[...] a movement, a system that is so flexible and open that it circumvents any rigid definition of 'health', 'culture' or 'service"'. Therefore, they are strategic devices, because they activate experiences that go beyond health boundaries, in the promotion of intersectoral practices and in the creation of meetings in the territory, through the production of care based on conviviality.

In the following, we will describe in more detail the development process of the Forum meetings, the process of collective learning, the construction of a theoretical path, and the results of this experience.

\section{The Forum}

In the concept of the common, as proposed by Hardt et al. in 'Multitude' $\mathbf{8}$ and 'Commonwealth'9(178), we found a point of connection with Spinoza. In 'Ethics IV'10, in the comment of proposition 35, Spinoza states that "there are many more advantages than disadvantages in the 'common' society of humans"9(178); and that

through mutual help, humans get much more easily what they need, and that 'just by gathering their forces' they can avoid the dangers that threaten them everywhere ${ }^{\mathbf{9}(178)}$

We would like to point out that 'gathering these forces' can be thought of as a power of the 'common'. In addition to avoiding the dangers that threaten us, this union of forces opens the possibility of imagining and creating other worlds together, other ways of living. Regarding SUS, there are several dangers that threaten us. In the case of mental health policies, the feeling is that the dangers are getting worse every day. SUS in Rio de Janeiro already had the worst SUS Performance Index (IDSUS) among the capitals across the country ${ }^{11}$.

These indexes help elucidate the situations that the workers go through, in this journey between the 2016-2019 period, in which the municipal SUS of Rio de Janeiro suffered very harsh attacks: entire teams were dismissed in 
primary and psychosocial care, family clinics were closed, with emphasis on the year of 2019 when the justice needed to intervene in the municipal management in defense of the unassisted population and workers without payment ${ }^{12}$.

In a national context, we can see that, before the 2016 coup, the data indicated a significant path already taken towards dehospitalization and the consolidation of essentially community-based psychosocial care:

Considering the investment in psychosocial care services, especially in Caps, which in '2014' exceeded the amount of 2 thousand reais, and reached a coverage of 0.86 Caps per 100 thousand/inhabitants. Hospital expenditure fell from $75.24 \%$ in ' 2002 ' to $20.61 \%$ in ' 2013 ', while, reversing the policy, psychosocial care expenditure goes from ' $24.76 \%$ 'to ' $79.39 \%$ 'in the same period ${ }^{13(2072)}$.

Until 2015, when the Ministry of Health stopped publishing information regularly, we observed, through the data presented, that public investment in Caps-type services was increasing, which strengthened the psychosocial model of care proposed by the RPB, the replacement of the hospital-centered network by community and territorial services.

Back in the context of Rio de Janeiro, the manifestos of social movements expose the concrete harmful effects on daily life. The report of the Núcleo Rio Sem Manicômios, entitled 'A saúde mental adoece!' (Mental health is getting sick!) ${ }^{\mathbf{1 4}}$, published in 2019, stated that users of mental health services who received Bolsa Rio (indemnity scholarship for people who had been hospitalized for two uninterrupted years or more before the Psychiatric Reform law) had not received it for two months; some Caps did not have food to offer users, that is, the users were starving; therapeutic residential services had rents overdue, with residents being threatened with eviction, in addition to caregivers who had not been paid for three months. There were power outages in Caps in 2019 because the city hall did not pay the electricity bill; the city did not invest in community-based services but financed psychiatric hospitals by designing an increase in the number of beds.

Amid this scenario of dismantling SUS, how to maintain the strength to build? How can we not lose our imagination and creative capacity in the face of the terrible news that hit us daily?

Let us move on in the track of the common. The common is taken as multiplicity, as a compound of singularities, which are established in the common. The common is based on the communication between singularities that manifests itself through the collaborative social processes of production. The common is not given, but it is produced and tends to shift the dichotomies between individual and society, subjective and objective, private and public.

The common is, at the same time, a precondition and result of the production of the multitude. It makes it mobile and flexible. And the multitude does not refer to a single 'identity' of people or to a 'uniformity' of the masses, but the 'differences in communication' are those that allow the common to be produced and to act together.

Without disregarding the ambivalent conditions for the emergence of the multitude, which can lead to both liberation and a new regime of exploitation and control, we understand the multitude as a project of political organization, which can only be achieved through social practices.

The following question remains: how can we constitute social practices and movements in which 'active forces prevail over reactive forces'? We share here the history of the Ceco Forum during the period of 18 months, from May 2018 to November 2019, in 8 editions, understanding that it is, simultaneously, product and process of the movement that discusses the politics of conviviality.

We believe that transformations happen through (good) meetings, which increase the capacity of acting and thinking. On May 
8, 2018, 50 years after May 1968, during the first meeting, for the first time, the Ceco of the state of Rio de Janeiro were together and their different ways of working were discussed. On this occasion, the Practical Guide to Solidarity Economy and Mental Health - 'Dá pra fazer!' (We can do it!) - was launched. Elaborated in 2017 by authors who brought different experiences in the fields of mental health and solidarity economy, it is a product that integrates a set of activities supported by the CNPq notice No. $89 / 2013$, related to the implantation of the Technological Incubator for Popular Cooperatives of IFRJ. We were more than 200 participants linked to about 70 collectives and/or different institutions. We were a small crowd of users, workers, family members, managers, students, researchers, and activists from various fields, such as health, art, culture, and solidary economy.

The first meeting preceded two premeetings, one in the Center-South Zone of the city of Rio de Janeiro and the other one in the North-West Zone, with the aim of collectively constructing how we would organize the different agendas that were to be discussed. When making the invitations to compose the roundtables of the meeting, we noticed an enormous readiness of the professionals to talk about their work. It became clear that the topic of the work developed in Ceco is extremely sensitive. The experiences shared looked more like a roundtable event since there were ten people around it. There were six Ceco experiences presented in one hundred and thirty minutes to an audience extremely interested in each word. Everyone listened to what each one was doing, and each group had different activities.

In the final plenary session, we gathered and read out loud all the proposals of the working groups. After a few highlights, we have approved a set of proposals to prepare a political document: the 'Letter from the CECO in Rio de Janeiro'. We closed this first meeting with the embryo of the letter in our hands and the feeling that it was a powerful meeting.
However, only one day was not enough. There were many challenges to be faced together. We then decided to create the Permanent Forum of Community Centers in the State of Rio de Janeiro. The first meeting gave rise to three products: the Letter, the Forum and, later on, the Bill (PL) No. 4,563/2018.

\section{Forums, itinerancy, the power of the common: the method of reasoning with feet}

In this section, we will describe the Forums that were proposed during the first Meeting and their main discussions. We will use the narrative in the first-person plural, as we are all part of the process that was established: from organizers of the first meeting, we were able to create a militant collective that continued to meet regularly in favor of advances in RPB, considering specifically the Ceco device. As already mentioned, we believe that it is in the meetings that we can aim at transforming, as well as producing knowledge that is involved in these actions with the collective.

At the first Forum, also at Uerj, we evaluated the first Meeting and moved on to the Letter and discussed 11 proposals organized in 3 axes: legislation and financing; infrastructure; and training. It was suggested that we should create a commission dedicated to legislation, and promptly there were six volunteers. We agreed that the letter would be printed and supporting signatures would be collected. We agreed that the forums would be held in different to increase the participation of cohabitants and local communities. This was also a way for everyone to get to know the neighborhood, the access, the air, and the places of each Ceco, using the method of 'thinking with the feet'15, the one who walks and lives the daily life.

The second Forum took place at the Ceco in Campo Grande (West Zone), which has the specificity of operating within a cultural 
canvas. In the city of Rio de Janeiro, Cultural canvas is the common name given to a series of sheltered theaters, administered by the Secretariat of Culture in the city.

The topics on the agenda were: urban mobility, commercialization of solidarity economy products, and strategies for letter dissemination. However, in addition to the planned agenda, there was a real agenda: to know how the relationship in the territories with canvas is. The collective started to think about strategies to implement Ceco via other cultural canvas, such as in that successful partnership in Campo Grande. The idea was that workshops that took place inside Caps could take place outside, on canvas, and be open to the whole community. In this scene, we clearly saw how the Forum enables a dialogue that expands the power of action of the collective of workers from Cecos and Caps. In addition, the creation of a website was suggested as a strategy to communicate the letter and disseminate the Forum in the virtual world.

The third Forum took place at the Museum of Contemporary Art, organized by Ceco in Niterói, in the state of Rio de Janeiro. Each of the more than 70 people presented themselves saying their names and what had taken them to attend the meeting, which moved many participants. A way of creating a Forum was established and divided into two moments: in the first one, the focus was on the place, in which the Ceco responsible for hosting the event presents its way of conviviality and its partnerships. In the second one, the focus is on the problems common to all. They are discussed and collective strategies are considered. The issue of what conviviality activity means was intensely debated. We focused on creating answers to the question: what is indispensable at a Community Center? Conversations, people who understand us, union, loyalty, harmony, support, better reception, coordinator, supervisor, psychologist, support from the city hall, van, bus, music, opportunities for courses and work, social security, records of the actions taken.
The theme of social voucher/free pass has returned as something essential for transit in the city. This is a struggle not only for the Community Centers, but it also represents the right to have cultural, artistic, and leisure practices from one public space to the other. Then, the word 'treatment' appears because the right for free transportation seems to be assured when it is for treatment, even with restrictions.

Some statements have advocated Community Centers as a kind of treatment. Is that what we want? To consider it as treatment? Who treats, and treats what? For whom is the Community Center? The need for dialogue between Caps-Ceco teams was mentioned. In the end, among many possible definitions of treatment stood out among those who use Ceco: treatment is health, it means being free to the world, it means living everyday life.

Formal 'academic' knowledge is disassembled and reassembled in meetings with those using the device. If we say that conviviality also means managing controversy, that we are living together in the Forum, it is necessary to operate this ethics, in which multiple forces in tension co-emerge. This passage can be linked to what Schwartz \& Ruzza ${ }^{16}$ state. When correlating militant activity - in this case, 'union knowledge' and the development of knowledge - the authors base themselves on the hypothesis that the knowledge produced at the confluence of the militant experience with the transmission of knowledge is marked by a specificity that has a triple requirement: 1) pedagogical requirement, as they must be assimilated by the militants, by the group of workers; 2) analytical requirement since the union organization has an obligation to understand and interpret the movement of society and the job world; 3) practical-normative requirement, to provide the means to act in and on this society and this world.

In our analysis, although the Forum is not a union organization but a political movement, it is subject to this triple requirement 
that the authors highlight. The Forum has researchers, teachers, and university students. The pedagogical and analytical dimensions interfere with practical-normative requirements, such as, for example, the preparation of political documents. The Letter of Ceco already has hundreds of signatures, and we propose to send it to the parliamentary front in defense of mental health and anti-asylum struggle of the Legislative Assembly of the State of Rio de Janeiro (Alerj). The fact that the movement gains more and more participants produces joy in the collective, and we learn from Spinoza in 'Ethics IV' Proposition 18 that "the desire that arises from joy is, under equal circumstances, stronger than the desire that arises from sadness"10(168). We feel that there is a predominance of active forces over reactive forces.

In its fourth edition, the Forum was held in Ceco Trilhos do Engenho, in Engenho de Dentro. More than 80 cohabitants participated in the forum, some of whom had been through long psychiatric hospitalizations and others through shorter ones. Many spoke of the positive changes that they perceived in their lives after their participation in Ceco. One person said that before she considered herself really shy, that she could not even go to the gate, and today she goes to the city center and is passionate about the life she has.

In the second stage, the draft text of the bill formulated by the legislation commission was presented and discussed. The topic about the Ceco team brought many controversies to be handled, and multiple forces under tension coemerged. Can a professional with elementary education be hired? Does the professional need to have finished high school? Does handicraft require formal education? Is it necessary or not to mention in the text of the bill all the 14 health professions? Which ones are included, and which ones stay out?

We had an intense democratic experience, a direct democracy, without a representative, in which everyone's voice, whoever it was, was heard and considered as a right. The authors' understanding of the analysis of this process with regard to democracy is based on Spinoza in the Political Treaty:

This right, which is defined by the power of the multitude, is usually called STATE, and is in full possession of that right, who by common consent, watches over public things, that is, establishes laws, interprets them, abolishes them, fortifies cities, decides on war and peace, etc. If all of this is done by an assembly from the mass of the people, the State is called DEMOCRACY17(43).

The democratic experience of the construction of the bill that creates the State Policy of the Conviviality Centers of the Psychosocial Care Network in the State of Rio de Janeiro - bill No. 4.563/201818 - leads us to list three different directions of public policies. The first one is related to policies concerning a specific government, or mandate: the policy is public since it serves the population, but its end is marked when a given term ends. The second sense has to do with the State, in this case, public policy is state policy that goes beyond the end of a government, it is more institutional than government policies, being incorporated in such a way that it cannot be easily extinguished when certain term ends. The third sense, which is what we exercise in the experience of the Forum, concerns public policies that refer to common management ${ }^{8}$.

The sense of public is linked to popular participation, which actively builds politics, and which, in this case, promotes health because it is also an activity of coexistence in the context of Ceco. The Forums started to be incorporated as an activity within the cultural agenda of some Ceco, indicating the inseparability between attention and management.

The next Forum, in its fifth edition, was organized by the Cultural Interventions Center of the Municipal Institute Philippe Pinel, in Botafogo. Many artistic and cultural projects in the Central-South Zone were present, and the carnival theme was striking. 
We realized that, although there is no Ceco in that area of the city, Praia Vermelha has a solid cultural vocation.

For many years there has been a project to develop a Ceco in the South Zone. We discovered that bill No. $4,563 / 2108^{18}$, filed at Alerj at the end of 2018, will pass through five committees before being brought to vote. We agreed to follow this process by meeting with these commissions, when necessary. The day before the public hearing at Alerj that would guide the State as a co-financier for Raps and we were mobilized. We made a banner that called for the approval of bill No. 4,563/2018 ${ }^{18}$ and it was hung at Alerj during the hearing.

The sixth Forum was held at the Experimental Center for Conviviality, Education and Culture, in Jacarepaguá. The spirit of the month of the anti-asylum struggle was already felt by the collective. The day of the anti-asylum struggle, on May 18, was about to be celebrated at Circo Voador, a historical space of resistance of art in the city since the 1980s.

The Forum body was determined and acted in the affirmation of a policy of conviviality. We talked about making Circo Voador, on that Saturday, May 18, a great Community Center, and that happened. The organization of the Circular da Loucura event at Circo Voador was a joyful common production that concentrated the participation of diverse movements: anti-asylum struggle, agroecology, black feminism, popular culture, homeless population, solidarity economy, among others. In this experience, there was an agreement between the different movements for power, for the affirmation of life in freedom, for the affirmation of conviviality in the city, as a politics. In this experience, we analyzed, in the light of Spinoza's philosophy, that things were agreeing in nature, that is, agreeing in potency, and not in impotence or in denial, according to 'Ethics IV'10 Proposition 32.

The seventh Forum took place at the Professor Jair Nunes Macuco Cultural Center, which houses Ceco in the city of Carmo, in the countryside of the state, 200 kilometers from the capital. Two buses with more than 40 people and 2 vans with 15 people headed from the cities of Rio de Janeiro and Niterói to Carmo to get to know the experience of having closed a mental hospital and giving space to a powerful and articulated health network.

The experience of the Forum in Carmo made it clear that the activity of conviviality is embedded in the purpose of the Forum, in addition to a debate on the macro-political sphere. We spent more time traveling, listening, playing, singing, making music, poetry, theater, feijoada than dedicating ourselves to the agenda. It was possible to consider a way of doing politics that understands the activity of conviviality as anti-asylum work full of affection, the one that makes us "build concepts and invent practices that operate in the full productive field of sociability and life"19(124).

However, the micro and macro-political dimensions are inseparable. The Forum is also concerned with the fact that the Ceco do not have financial support or their own resources (they do not have a budget allocation), they do not operate without the recognition of management (they do not have a SUS record: National Registry of Health Facilities - CNES), there are no parameters for carrying out this work (they do not have a national ordinance that regulates them). For this reason, the seventh Forum was also a space to guide the participation in the XVI National Health Conference, through two elected delegates, who put forward a motion on behalf of the Ceco that received more than $90 \%$ approval and was articulated with other states of the federation. It was also possible to talk about bill No. 4,563/2018 ${ }^{18}$, already approved in four of the five commissions of Alerj.

The eighth and last Forum of the year 2019 took place at the Federal Fluminense University (UFF), in the Marielle Franco auditorium, on the Gragoatá Campus. This Forum took place nine months after the first one of that year, and it is interesting to see that the Collective Convivencias of the Federal University of Rio de Janeiro (UFRJ) came 
into action at the Praia Vermelha Campus, aimed at thinking and conducting experiences that reflect the collectivity and conviviality, in dialogue with the activities and studies of SUS' device - Ceco. It was created exactly in an area of the city that did not have a Ceco, despite of plans from long ago.

In our analysis, the emergence of this collective is the result of the development of the dialogical capacity of workers provided by different spaces, including the Forum. Once again, we confirm the hypothesis of the conviviality activity as production of the common. Therefore, the experience with the Forum provides us with three valuable clues about the activity of conviviality, which can also serve as inspiring elements in the construction of policies and movements: 1) Openness, being open to everyone's participation, with no restriction; 2) Itinerancy, moving without settling in the same place; 3) Multiplicity, wanting differences and not obstructing the path.

\section{The policy of conviviality in defiance of neoliberalism}

The path mentioned above explains how the activity of conviviality is constituted by the construction of this common plan. A plan in which a social body reappropriates its creative power, its conatus, and is able to act, to transform reality. Then, we arrived at the formulation of the thesis that the activity of conviviality is the production of the common, of this plan that is, at the same time, "what we share and in which we take part, we engage and belong to"20(21).

This scenario is set in times of an epidemic of psychiatric drugs ${ }^{21}$, of medicalization and pathologization of life, of attacks against SUS and democracy. According to Hardt et al.22, neoliberalism and its crisis introduced some subjective figures, which we highlight in our analysis: 1) the indebted, which is produced by the hegemony of finance and suffers from the impoverishment of life that was sold to capital;
2) the mediatized, produced by the control of information and who suffers because its attention is constantly absorbed by the screens; 3 ) the securitized, produced by the regime of (in) security in the state of exception, who suffers from watching and being watched, driven by fear; and 4) the represented, produced by the corruption of democracy.

In view of these problems, we think that it is urgent to meet in person, to strengthen the common. The Forum began to be outlined as the same space in which the effects of the Ceco experience on the life of those living together are discussed and public policy is built. When we use the expression 'living together', we are twisting it. We recognize that, although there are differences between the various enunciators (user, Ceco's worker and of other devices, manager, family member, student, partner, researcher, activist, artist), by proposing that we are all living together, we try to blur these boundaries instituted, so that everyone can transform themselves in the experimentation of other places. This trait points to the power of multiplicity. The more we can get in touch with what is new and different, the more powerful we will become, according to 'Ethics IV'10, Proposition 38.

It seems that there is a razor edge there. In the constituent process for a policy of conviviality, we affirm the life, freedom, and joy that are produced in the meetings. However, we are aware of the risks of bondage in the name of freedom. We do not know what is yet to come, what may result after the approval of ordinance No. $4.563^{18}$, for example. The content of this project defines the Community Center as an intersectoral device that is part of Raps, designates its responsibility, foresees the composition of the team, and states that Ceco cannot prescribe medication or provide psychiatric or psychotherapeutic care. We trust in the power of the common to break with subdued subjectivities: we hope that we can stop being indebted and create other productive interdependencies, that we can stop being mediatized and break the spell on the screens by inventing 
other ways of communicating that strengthen political affections; that we can stop being securitized and free ourselves by stopping feeding and being fed by fear; that we can, instead of positioning ourselves as someone represented, constitute ourselves and speak with our own voice in the exercise of democratic actions.

The defense of the collective, of the creation of movements, of the Permanent Forums, based on meetings, appears as resistance in the face of the neoliberal way of organizing a society and in the face of increasingly serious threats that we suffer. We believe in the power of social ties, in encouraging the protagonists that shape democratic practices.

The resistance movement, therefore, is built through the social, collective creation, of the group, and is constituted in the power relations that are established in a macro-political context. Like Barros ${ }^{23(57)}$, we do not consider resistance "[...] as something external, which stands against power. It is the action in the relation of power". We believe that the collective's creation movements, in this sense, are constituted in resistance, in the production of protagonists, of desiring subversions amid the dominant and individualizing power mechanisms that are currently present.

\section{Final considerations: for mutant portraits of the Brazilian Psychiatric Reform}

Ceco are devices aimed at promoting meetings. The movement we created around the device, in this sense, is based on the idea of collective production, of joint creation, in the search for the sustainability of the policy of conviviality. In a neoliberal context, in which we experience serious setbacks in the scope of social policies, we believe that it is necessary to strengthen community-based devices, such as the Ceco, encouraging policies to promote health in the territory.
We assume that there is a need for a permanent deinstitutionalization process. There is a polysemy of the term deinstitutionalization. Here we are interested in the perspective of deinstitutionalizing, not as dehospitalizing, i.e., reducing psychiatric beds, or as transferring the patients from one institution to another. We refer to the deinstitutionalization of insanity as a transformation of relations of power between institutions and subjects. Deinstitutionalization as an individual and collective process of emancipation, liberation, which has the component of individual suffering, but which cannot be reduced to it. It involves workers, public managers, politicians, ordinary citizens, in the utopian search of, but, paradoxically, achievable, a society without asylums ${ }^{24}$.

Another aspect of the policy of conviviality, in terms of its deinstitutionalizing dimension, is the deconstruction of the asylum through elementary gestures. As Rotelli states ${ }^{25}$, elementary gestures have to do with eliminating the means of containment; reestablishing the individual's relationship with his/her own body; reconstructing the ability to use personal objects; rebuilding the right and the ability to speak; eliminating ergotherapy; opening doors; producing relationships, spaces, and objects of interlocution; releasing feelings; restoring civil rights by eliminating coercion, legal protection, and the dangerous status; reactivating an income base to be able to access social exchanges.

We understand that the strength of this collective movement was only possible in the context of advancing the achievements of the RPB, which allowed the stabilization in the national territory, now at risk, of a community network of mental health care.

The trajectory of this instituting movement for Social Centers in the public field of psychosocial care points out to the establishment of intersectoral policies that guarantee access to a wide range of cultural, 
*Orcid (Open Researcher and Contributor ID). social, and economic rights for groups linked to mental health services. They are mutant portraits in continuous processes of transformation of the RPB brought about by the political subjects that inhabit this place to make life possible for everyone. For everyone.

\section{References}

1. Brasil. Ministério da Saúde. Reforma psiquiátrica e política de saúde mental no Brasil. In: Anais da Conferência Regional de Reforma dos Serviços de Saúde Mental: 15 anos depois de Caracas [internet]; 2005 Nov 7-10; Brasília, DF. Brasília, DF: Ministério da Saúde; 2005. [acesso em 2019 out 12]. Disponível em: http://bvsms.saude.gov.br/bvs/publicacoes/Relatorio15_anos_Caracas.pdf.

2. Baremblitt FG. Compêndio de análise institucional e outras correntes: teoria e prática. Rio de Janeiro: Rosa dos Tempos; 1992.

3. Brasil. Ministério da Saúde. Saúde Mental em Dados. [internet]. 2012. [acesso em $2020 \mathrm{fev} 29$ ]; 11. Disponível em: http://psiquiatriabh.com.br/wp/wp-content/uploads/2015/01/Dados-da-rede-assistencial-brasileira-2012-Ministerio-da-Saude.pdf.

4. Pacheco RF, Silva CR. (Com) Viver com a loucura: por um cuidado extramuros. Rev. Polis Psique [internet]. 2018 [acesso em 2020 fev 29]; 8(2):140-161. Disponível em: https://seer.ufrgs.br/PolisePsique/ article/view/78136/pdf.

\section{Collaborators}

Alvarez APE (0000-0003-1067-209X)*, Almeida NMC (0000-0002-9463-739X)*, Figueiredo AP (0000-0003-1464-3907)* also contributed to the preparation of the manuscript.

5. Brasil. Ministério da Saúde. Portaria $n^{0} 3.088$, de 23 de dezembro de 2011. Institui a Rede de Atenção Psicossocial para pessoas com sofrimento ou transtorno mental e com necessidades decorrentes do uso de crack, álcool e outras drogas, no âmbito do Sistema Único de Saúde (SUS). Diário Oficial da União. 23 Dez 2011.

6. Brasil. Ministério da Saúde. Portaria no 3.588 , de 21 de dezembro de 2017. Altera as Portarias de Consolidação $n^{\circ} 3$ e $n^{\circ}$ 6, de 28 de setembro de 2017, para dispor sobre a Rede de Atenção Psicossocial, e dá outras providências. Diário Oficial da União. 21 Dez 2017.

7. Ferigato SH, Carvalho SR, Teixeira RR. Os Centros de Convivência: dispositivos híbridos para a produção de redes que extrapolam as fronteiras sanitárias. Cad. Bras. Saúde Ment. [internet]. 2016 [acesso em 2020 fev 20]; 8(20):80-103. Disponível em: http:// pepsic.bvsalud.org/scielo.php?script=sci_arttext\&p id=S1984-21472016000300006.

8. Hardt M, Negri A. Multidão: Guerra e democracia na era do Império. Rio de Janeiro: Record; 2005. 
9. Hardt M, Negri A. Bem-estar comum. Rio de Janeiro: Record; 2016.

10. Spinoza B. Ética. 2. ed. Belo Horizonte: Autêntica; 2009.

11. Nalon T. Rio é capital com pior avaliação do atendimento do SUS, diz governo. [internet]. G1. 2012 Mar 01 [acesso em 2020 fev 29]. Disponível em: http:// g1.globo.com/ciencia-e-saude/noticia/2012/03/rio-e-capital-com-pior-avaliacao-do-atendimento-do-sus-diz-governo.html.

12. Regueira C. Mais de 22 mil prestadores de serviço para a saúde do Rio estão com os salários atrasados; Justiça manda bloquear R \$ 320 milhões. [internet]. G1. 2019 Nov 26. [acesso em 2020 fev 29]. Disponível em: https://gl.globo.com/rj/rio-de-janeiro/ noticia/2019/11/26/mais-de-22-mil-funcionarios-que-prestam-servico-para-a-saude-do-rio-estao-com-os-salarios-atrasados-justica-manda-bloquear-r-320-milhoes.ghtml.

13. Amarante $\mathrm{P}$, Nunes MO. A reforma psiquiátrica no SUS e a luta por uma sociedade sem manicômios. Ciênc. saúde colet. [internet]. 2018 [acesso em 2020 fev 29]; 23(6):2067-2074. Disponível em: http://www.scielo.br/scielo.php?pid=S1413$-81232018000602067 \&$ script=sci_abstract\&tlng=pt.

14. Núcleo Estadual do Movimento Nacional da Luta Antimanicomial do Rio de Janeiro. [internet]. [acesso em 2020 jan 16]. Disponível em: https://www.facebook.com/lutaantimanicomialrj/.

15. Venturini E. O caminho dos cantos: morar e intersetorialidade em saúde mental. Fractal: Rev. Psicol. [internet]. 2010 [acesso em 2020 jan 22]; 22(3):471-480 Disponível em: http://www.scielo.br/scielo.php?script=sci_abstract\&pid $=$ S1984$-02922010000900002 \& \operatorname{lng}=$ pt\&nrm=iso\&tlng=pt.

16. Di Ruzza R, Schwartz Y. De l'activité militante à elaboration de savoirs. Education Permanente [internet]. 2003 [acesso em 2020 fev 20]; 154(1):1-9. Disponível em: https://halshs.archives-ouvertes.fr/ halshs-00095787.
17. Spinoza B. Tratado Político. Rio de Janeiro: Nova Fronteira; 2013.

18. Rio de Janeiro. Assembleia Legislativa do Estado do Rio de Janeiro. Projeto de Lei ${ }^{\circ} 4.563$, de 20 de dezembro de 2018. Cria a política estadual dos centros de convivência da rede de atenção psicossocial no estado do Rio de Janeiro. 20 de dezembro de 2018 [internet]. [acesso em 2019 out 15]. Disponível em: http://alerjln1.alerj.rj.gov.br/scpro1519.nsf/18c1dd6 8f96be3e7832566ec0018d833/6fe33ee2aaf668a103 2583690053706 e? OpenDocument.

19. Lancetti A. Clínica Peripatética. São Paulo: Hucitec; 2008.

20. Kastrup V, Passos E. Cartografar é traçar um plano comum. In: Passos E, Kastrup V, Tedesco S, organizadores. Pistas do método da cartografia: a experiência da pesquisa e o plano do comum. Porto Alegre: Sulina; 2014. p. 15-42.

21. Whitaker R. Anatomia de uma epidemia: pílulas mágicas, drogas psiquiátricas e o aumento assombroso da doença mental. Rio de Janeiro: Fiocruz; 2017.

22. Negri A, Hardt M. Declaração - Isso não é um manifesto. São Paulo: N-1 edições; 2016.

23. Barros RB. Grupo: A afirmação de um simulacro. 3. ed. Porto Alegre: Sulina; 2009.

24. Venturini E. A linha curva: o espaço e o tempo da desinstitucionalização. Rio de Janeiro: Fiocruz; 2016.

25. Rotelli F, Leonardis O, Mauri D. Desinstitucionalização, uma outra via. In: Nicácio F, organizador. Desinstitucionalização. 2. ed. São Paulo: Hucitec; 2001. p. 17-59.

Received on 03/01/2020

Approved on 08/18/2020

Conflict of interests: non-existent

Financial support: non-existent 